\title{
QUALITY OF POPULATION DOCUMENT PUBLISHING SERVICE OF MIGRATION CITIZENS AFFECTED BY CISUNDAWU TOLL PROJECT IN RANCAKALONG DISTRICT SUMEDANG REGENCY
}

\author{
Rika Kusdinar $^{\left.a^{*}\right)}$, Ramdani $^{a)}$ \\ ${ }^{a)}$ Sekolah Tinggi Ilmu Administrasi Sebelas April, Sumedang, Indonesia \\ ${ }^{*}$ Corresponding Author: yfirzal@eng.unri.ac.id
}

Article history: received 09 January 2021; revised 13 January 2021; accepted 26 January 2021

\begin{abstract}
This study aims to analyze problems regarding service quality, inhibiting factors of service quality, and efforts to improve the quality of service for publishing population documents in the integrated services section in Rancakalong District, Sumedang Regency. The method used in the preparation of this thesis is qualitative research methods. Data collection techniques are carried out through library research and field studies which include: observation, interviews, documentation study, and triangulation. The determination of the sample / informant in this study was carried out using purposive sampling. Furthermore, data analysis is carried out by referring to the technical analysis of the miles and Huberman models, namely: data reduction, data display, and conclusion drawing / verification (conclusion). Sources of data / informants in this study are: Head of Sub-District, Head of Sub-District Secretariat, Public Service Sub-Division, Head of General Subdivision, Assets and Administration, Governance Section. Based on the results of interviews, observations and documentation results, data analysis is then obtained that the quality of service for the publication of population documents at the service section of Rancakalong District, Sumedang Regency can be said to be quite good, it can be seen in the aspects of reliability, tangibles, responsiveness, assurance, and empathy. Although there are still obstacles that occur in the process of improving service quality, namely service procedures and service flows that not many people understand or have not been maximally socialized to the community. Efforts are made to overcome barriers to improving service quality, namely by the existence of effective communication, giving authority, giving motivation, training on services.
\end{abstract}

Keywords: service quality

\section{INTRODUCTION}

As time goes by and the work program of the central government which is intensively carried out in implementing infrastructure development in various regions in Indonesia, has an impact on the conversion of productive land functions and also settlements into buildings or public infrastructure which have an impact on population displacement. This is also a problem if it is not handled properly. As in the case of the Cisundawu Toll Road Development in Sumedang Regency.

Due to the legal mandate of the Sumedang Regency Regional Regulation number 6 of 2015 concerning the Implementation of Population Administration, Rancakalong District government as a Regional Work Unit hereinafter referred to as (SKPD) is obliged to carry out the mandate of regional government as an autonomous right delegated by the center to manage population administration in the framework of proper administrative order as mandated in Law number 24 of 2013 concerning Population Administration and Civil Registry, as an object namely residents affected by the Cisundawu Toll Road Development in Sumedang Regency, the publishment of population documents is indispensable in order to carry out good and effective population administration at the District government level. against residents who report significant events related to population movement or migration.
The impact of the Cisundawu Toll Road Project in the analysis is located in Rancakalong District, Sumedang Regency, which has an area of 5,228 (Ha) with hilly conditions and rice fields as connecting the national strategic area of the Bandung Basin with West Java International Airport in Kertajati and helping to reduce congestion in Jalan Cadas Pangeran, the impact on population changes caused by the construction of the Cisundawu Toll Road Project will clearly cause various phenomena or population events, one of which is migration or population displacement caused by displacement of residents and the conversion of productive community land to toll road project or toll road construction.

This phenomenon or population is clearly become a task for the local government of Rancakalong District, Sumedang Regency and working apparatus at the Village level, who directly face the community in the implementation of population administration services, with the result or output of service in the form of publishing population documents in the framework of administrative order.

Based on the researchers' initial observations, the problem phenomenon regarding the Publishing of Population Documents can be seen from the following indications: Lack of good handling by the government regarding the move. Residents still feel that the recording or registration and recording of population data were not conducted seriously. 
This means that there is no updating of reporting population events and other important events that occur in the publishing of population documents. Apparatus discipline is still minimal and lack of adequate human resources in terms of quality due to the slow service provided in the Service section of Rancakalong District, Sumedang Regency. So that the service has not been conducted optimally. The low level of work produced by employees. This is evidenced by a lot of complaints from the citizens regarding the public services provided, individualism and the lack of cooperation between employees in solving work problems, such as the slow pace of making electronic residence identification card ( $E-K T P)$.

Such population problem left a task for the Rancakalong District government which was given the obligation to carry out services related to the publishing of population documents in the context of orderly population administration in order to build population data through registration, so service becomes the main pillar of this implementation.

According to Morgan as cited in Zaenal [1], "quality is the of feature of a product service that bears on its ability to satisfy given needs". Quality is a special form of a production or service that has the ability to satisfy the needs of society. According to Zeithaml [2], Service Quality is "Service quality is the extent of discrepancy between customer's expectations or desires and their perceptions". (approximately it means that service quality is a mismatch between the expectations or desires of consumers and consumer perceptions).

Population administration is inseparable from the matters relating to the autonomy of the implementation and management of population administration carried out by the regional government in terms of making documents related to population. These documents must be fulfilled by persons residing in a State which provide information and data on the person's whereabouts which is carried out in accordance with the prevailing laws and regulations. Population Administration based on Law Number 24 of 2013 concerning Population Administration and Civil Registration is a series of activities to determine and control population documents and data through population registration, civil registration, management of Population Administration information and utilization of the results for public services and development of other sectors. Nigro and Nigro (Islamy [3]) stated that "State administration has a very important role in formulating state policy and is therefore part of the political process". Meanwhile Waldo in Iskandar [4] identifies state administration as "State Administration as an organization and management in government in order to achieve predetermined goals". Furthermore Dimock in Iskandar [5] stated that: "State Administration includes all steps taken between the time an executing body accepts authority and when the final stone is laid". Shafritzs [6] stated that "Public management is a branch of the broader field of science, that is State administration". So public management is a technical sub-sector of public administration (technical sub-fieldof public administration).
According to Morgan (as cited in Zaenal [1], quality is the of feature of a product service that bears on its ability to satisfy given needs. "Quality is a special form of a production or service that has the ability to satisfy people's needs". Zeithaml [2] stated that the value of good service quality can be measured from five dimensions, namely: Tangible with indicators of facilities and infrastructure as well as the comfort of the place in providing services. Reliability with indicators of accuracy of officers in serving customers and having clear service standards. Responsiveness with indicators that respond to each customer or requestor to get service and speed in processing service. Assurance with indicators of knowledge and abilities of employees as well as trust in members. Emphaty with indicators of attention and good communication and understand customer needs.

Service Quality Inhibiting Factors, There are several inhibiting factors that affect the quality of public services based on a balance in service quality according to Thoha in Arif [7], namely: Individual Factor, System Factor Efforts to Overcome Service Quality Inhibiting Factors. To overcome these inhibiting factors, several efforts can be made as stated by Pasuraman in Arif [7], namely: Effective ability, Motivation, Authority, Training,

\section{RESEARCH METHODS}

In this study, the method used is qualitative research methods or often called naturalistic methods, because the assessment is in natural setting and the results of qualitative research emphasize meaning rather than generalization. Qualitative research is research on descriptive research and tends to use analysis. Process and meaning (subject perspective) are emphasized more in qualitative research. The theoretical basis is used as a guide so that the research focus is in accordance with the facts of the field.

The definition of qualitative research methods according to Sugiyono [8] is as follows. Qualitative research method is a research method that based on the philosophy of postpositvism, used to examine the condition of natural objects, where the researcher acts as a key instrument, data collection techniques are carried out by triangulation (combined), data analysis is inductive, and the results of qualitative research emphasize the meaning rather than generalizations. As for those who are determined to be informants in this study are executors who are considered to have authority, information and are involved in publishing population documents in improving the quality of population data collection services to run effectively in Rancakalong District, Sumedang Regency. So the informants were 5 people. The location chosen by the researchers was in Rancakalong District, Sumedang Regency. Data collection techniques through library research and field studies, namely observation, in-depth interviews, documentation and triangulation. To process data from interviews and observations, the authors conducted data processing by referring to the Miles and Huberman Model data analysis 
techniques quoted by Sugiyono [8], namely: Data Reduction, Data Display, Conclucion Drawing/Verification, Triangulasi .

\section{RESULTS AND DISCUSSION}

The Quality of the Population Document Publishing Service of Migration Citizens affected by Cisundawu Toll Project in Rancakalong District Sumedang Regency.

\section{Tangibles}

Based on the Tangibles dimension in the Quality of the Population Document Publishing Service of Migration Citizens affected by Cisundawu Toll Project in Rancakalong District Sumedang Regency in Room Arrangement. This is evidenced by the room arrangement in Rancakalong District, Sumedang Regency, the service section of the service room is not large enough and the waiting chairs are not suitable for the number of people who come every day, the facilities and infrastructure are not sufficient, for example, there is a living room, waiting chairs, cameras and computers and the unavailability of photocopy machine. The service officers have neat appearance, for example, the officers wear clothes that are required that is a uniform attributes, there are also wearing batik clothes and speaking politely.

\section{Reliability}

Based on the dimension of Reliability (Reliability) in the Quality of the Population Document Publishing Service of Migration Citizens affected by Cisundawu Toll Project in Rancakalong District Sumedang Regency, the Service officers have been careful in providing services to the community due to the existence of standard operating procedures, service standards have been implemented by service officers in the District to the community to meet the needs of the community in population administration.

\section{Responsiveness}

Based on the dimensions of Responsiveness (Responsiveness) in the Quality of the Population Document Publishing Service of Migration Citizens affected by Cisundawu Toll Project in Rancakalong District Sumedang Regency, the service officers have responded well to every need that the community wants, such as asking every need of the community or what the community wants and directing it.

Services are always processed and completed quickly because of the Standard Operating Procedure, for example, as previously known, from the new village we serve it quickly and then directed to the population office for those who move. Service officers are able to provide clarity of service information. This is evidenced by the lack of socialization of service officers in terms of existing service flows, and other information even though the requirements are quite easy but there are still people who do not know what these things are for example the existence of information boards.
Based on the dimensions of Assurance in the Quality of the Population Document Publishing Service of Migration Citizens affected by Cisundawu Toll Project in Rancakalong District Sumedang Regency, the service officers in providing services are polite, friendly. They smiles and use polite words. The service officers are fully responsible for the services provided such as completing work on time.

\section{Emphaty}

Based on the dimension of Emphaty in the Quality of the Population Document Publishing Service of Migration Citizens affected by Cisundawu Toll Project in Rancakalong District Sumedang Regency, the officers maintain the confidentiality of community data served and serve according to applicable regulations in Rancakalong District, Sumedang Regency. The Standard Operating Procedures makes the Officers able to understand and meet the needs of the community and receive criticism or suggestions from the community. In accordance with the standard operating procedures, the community gets services according to their rights without any differentiation.

The Inhibiting Factors in the Quality of the Population Document Publishing Service of Migration Citizens affected by Cisundawu Toll Project in Rancakalong District Sumedang Regency.

1. Individual Factor

Based on the constraints in the Quality of the Population Document Publishing Service of Migration Citizens affected by Cisundawu Toll Project in Rancakalong District Sumedang Regency, the service officers with higher education are able to quickly provide a service and service officers who have more experience in serving but the level of education not high. Service officers are able to quickly use computer facilities and are always on time in processing a service in accordance with predetermined service standards, but there was an error in the equipment so it takes a long time.

\section{System Factor}

Based on the obstacles in the Quality of the Population Document Publishing Service of Migration Citizens affected by Cisundawu Toll Project in Rancakalong District Sumedang Regency, the community is easy to get information about work procedures but does not understand the service procedures. Not all people are able to understand and comply with existing service flows, for example lack of requirements such as the copy of identification card, family cardm and a permit form from Village to District.

Efforts to Overcome the Obstacles to Improve the Quality of the Population Document Publishing Service of Migration Citizens affected by Cisundawu Toll Project in Rancakalong District Sumedang Regency.

\section{Assurance}

1. Effective communication 
Based on effective communication efforts in in the Quality of the Population Document Publishing Service of Migration Citizens affected by Cisundawu Toll Project in Rancakalong District Sumedang Regency carried out by Rancakalong District, Sumedang Regency, the communication that takes place between service officers and the community has not been effective. The service officers had communicated well with the community. It can be seen from how service officers were able to receive and listen to the needs of the community who want to get services, as well as socialize in each UPT area of the Rancakalong subdistrict to fulfill the needs of the community properly.

\section{Motivation}

Based on the leadership motivation efforts carried out in the Quality of the Population Document Publishing Service of Migration Citizens affected by Cisundawu Toll Project in Rancakalong District Sumedang Regency carried out by Rancakalong District, Sumedang Regency, the employees were enthusiastic in serving the community. Spoken or written motivation given the leader such as authority at work, listening to suggestions, complaints in providing services, the leader always given motivation to employees such as provided opportunities for employees to innovate and be creative, given employees the right to listen to the needs of society, respected suggestions and given reward to the workers.

\section{Authority}

Based on the efforts of the Authority given by the leader to the officers in the Quality of the Population Document Publishing Service of Migration Citizens affected by Cisundawu Toll Project in Rancakalong District Sumedang Regency carried out by Rancakalong District, Sumedang Regency, the leader had given authority to his employees to solve every problem themselves, provided suggestions and solutions as well as provided clarity of information that the community need.

\section{Training}

Based on the training efforts for officers to improve the Quality of the Population Document Publishing Service of Migration Citizens affected by Cisundawu Toll Project in Rancakalong District Sumedang Regency conducted by Rancakalong District, Sumedang Regency in the form of training in the District to improve service quality. This training was carried out only for internal, but there was also policies that the leader provides for employee training such as training for Administration Implementation and training on how to serve the community well.

\section{CONCLUSION}

Based on the discussion regarding the Quality of the Population Document Publishing Service of Migration Citizens affected by Cisundawu Toll Project in Rancakalong District Sumedang Regency conducted by Rancakalong
District, Sumedang Regency, the researchers conclusions are as follows:

1. The quality of service for making population documents in the integrated service division in Rancakalong Subdistrict, Sumedang Regency is in principle good enough by applying the characteristics of good service quality, but still not optimal, this can be seen from the characteristics of good service quality that are still has not been effectively implemented, based on other dimensions:

a. Tangibles, the arrangement of the room has been adjusted to the services to be provided, such as the service counters in accordance with the needs of the community but the service room is not large enough and the waiting chairs are not suitable for the number of people who come every day, the facilities and infrastructure are not sufficient, for example there is a living room, waiting chairs, cameras and computers and there is no photocopy mechine available. The service officers have neat appearance, for example, for example, the officers wear clothes which are required to wear the attribute uniform, there are also wearing batik clothes and speaking politely.

b. Reliability, careful in providing services to the community because of the Standard Operating Procedure, service standards have been applied by service officers in the District to the community to meet the needs of the community in population administration.

c. Responsiveness, responds well to every need that the community wants, for example, such as asking every need and directing it. Services are always processed and completed, for example, as previously known, from the new village then directed to the population office for those who moved. Service officers are able to provide clarity on available service information, such as information boards.

d. Assurance, friendliness of the service officers in providing services. They are polite, friendly, smiling, greetings people, and speaking polite words. They are fully responsible for the services provided to the community such as completing work on time.

e. Emphaty, security and comfort, maintaining the confidentiality of the data and serving according to applicable regulations in Rancakalong District, Sumedang Regency, Standard Operating Procedures, Service officers are able to understand and meet the needs of the community and accept criticism and suggestions from the community, in accordance with the standard operating procedures. People get services according to their rights without any differentiation.

2. There are some obstacles regarding the Quality of the Population Document Publishing Service of Migration Citizens affected by Cisundawu Toll Project in Rancakalong District Sumedang Regency, namely:

a. Factor, higher educated service officers are able to quickly provide a service and service officers who 
have more experience in serving but the level of education is not high. Service officers are able to quickly use computer facilities and are always on time in processing a service in accordance with predetermined service standards, but there is error in the equipment so it takes a long time.

b. The service procedure system factors. The community is easy to get information about work procedures but does not understand service procedures, not all people are able to understand and comply with existing service flows, for example lack of requirements such as the copy of identification card, family cardm and a permit form from Village to District.

3. Some efforts that has been conducted to overcome the obstacles to improve the Quality of the Population Document Publishing Service of Migration Citizens affected by Cisundawu Toll Project in Rancakalong District Sumedang Regency are as follows:

a. Effective communication on how service officers are able to receive and listen to the needs of the community who want to get services, as well as socialize in each UPT area of the Rancakalong subdistrict to fulfill the needs of the community properly.

b. Spoken or written motivation given the leader such as authority at work, listening to suggestions, complaints in providing services, the leader always given motivation to employees such as provided opportunities for employees to innovate and be creative, given employees the right to listen to the needs of society, respected suggestions and given reward to the workers.

c. The authority for employees to solve any problems themselves, provide suggestions and solutions and provide clarity of information that the community needs.

d. The training in the District for improving service quality is only internal, but there are also policies that the leader provides for employee training such as training for Administration Implementation and training on how to serve the community well.

Based on the results and discussion of the research, the authors propose several suggestions that can be taken into consideration by the implementation of government policies in Rancakalong District, Sumedang Regency:

1. Improving office layout, especially the space for storing population documents to make it easier for service officers to find information and data that has been entered.

2. Facilities and infrastructure for supporting services need to be renewed and equipped so that people can find services more easily and comfortably.

3. Effective communication as service officers are able to receive and listen to the needs of the people who want to get services, as well as socialize in each UPT area of the Rancakalong sub-district to fulfill the needs of the community properly.
4. Socialization given to the community regarding the procedures and flow of services in making Population Document administration.

5. Service officers should be able to provide the best explanation to the community regarding service procedures and service flows.

6. There is guidance for employees, so that employees are able to further improve their service quality.

Conducted monthly meetings to anticipate some obstacles in providing services to the community and evaluation meetings regarding services provided by SKPD.

\section{REFERENCES}

[1] Zaenal. (2015). Manajemen Pelayanan Publik. Bandung.CV Pustaka Setia

[2] Zeithaml, et.al. (1990). Delivering Quality Service. New York: Free Press.

[3] Islamy, M. Irfan. 2003. Prinsip-prinsip Perumusan KebijaksanaanNegara. Jakarta: Bumi Aksara

[4] Iskandar, J. (2016). Perilaku Manusia dalam Kelompok Organisasi. Bandung: Puspaga.

[5] Iskandar, J. (2016). Metode Penelitian Administrasi. Bandung: Puspaga.

[6] Shafritz, J. M., Russell, E. W., \& Borick, C. P. (2013). Introducing Public Administration: Pearson New International Edition. London, UK: Pearson Higher Ed.

[7] Arif, Mts. (2007). Pemasaran Jasa dan Kualitas Pelayanan. Jakarta: Banyumedia.

[8] Sugiyono.(2005). Metode Penelitian Administrasi. Bandung: Alfabeta. 